\title{
ANALYSIS FACTOR OF LOW BIRTH WEIGHT INCIDENCE IN RSUD GAMBIRAN KOTA KEDIRI
}

\author{
Anna Nurhidayati ${ }^{1}$, Melda Byba Suhita ${ }^{2}$, Indasah $^{3}$ \\ Graduate Program of STIKes Surya Mitra Husada Kediri \\ bubidelann@gmail.com
}

\begin{abstract}
Determinants of children in health status of community health status was infant mortality rate (IMR), One of the causes of infant mortality are low birth weight (LBW) 8 times greater than normal babies. The objective of this research was to analyze the effects of age, stress, parity, nutritional status, and anemia experienced by the mother during pregnancy that affect the incidence of low birth weight in RSUD Gambiran Kota Kediri. The design of this research was observational study design with cross Sectional (cross sectional study). This research was conducted on the 29th of July until 2nd of October 2017 in RSUD Gambiran Kota Kediri. The sample size of this study was 88 mothers of babies with low birth weight are treated in RSUD Gambiran Kota Kediri. The independent variables were age, stress, parity, nutritional status, and anemia experienced by the mother during pregnancy. The dependent variable was low birth weight. Data analysis using regression logistic multinomial with the results of the study showed age $(p$-value $=0.001)$, stress levels $(p$-value $=0.439)$, parity $(p$ value $=0.326)$, nutritional status ( $p$-value $=0.322)$, anemia gravidarum ( $p$-value 0.019). The results showed that the age of the mother during pregnancy and anemia gravidarum was significant effect on the incidence of low birth weight. Moderate levels of stress, parity, and nutritional status have no significant influence on the incidence of low birth weight in RSUD Gambiran Kota Kediri.
\end{abstract}

Keywords: maternal age, stress level, parity, nutritional status, anemia gravidarum, low birth weight.

\section{Background}

Determinants of health status of children of public health status is infant mortality rate (IMR). The cause of death of infants and toddlers is a problem that occurs in newborns / neonatal (0-28 days). Where is the problem in this neonatal include: asphyxia (difficulty breathing at birth), infants with low birth weight (LBW), and infections $(\mathrm{MOH}$, 2016).

Infant deaths due to low birth weight (LBW) 8 times greater than normal babies. Short-term risks and longterm will always overshadow infants with low birth weight (LBW) (Proverawati 2010). The decline in maternal and infant mortality rate is one of the goals of the Sustainable Development Goals (SDGs) or sustainable development goals which is a continuation of the Millennium Development Goals (MDGs) has ended at the end of 2015. At to objective number 3 , which ensures a healthy life and encourage prosperity for all people in all ages. One target is: in 2030, ending the infant and child mortality are preventable, with all countries trying to reduce neonatal mortality by at least 12 per 1,000 live births and the Infant Mortality Rate 25 per 1,000 live births (MOH, 2016).

In 2012 the World Health Organization (WHO) said that the incidence of LBW in the world in the range of 2005 to 2010 is $15 \%$ and in Southeast Asia the incidence of LBW Achieve 24\% where the highest rate found in the Indian State with a percentage of $28 \%$. Based on the results of Indonesian Demographic and Health Survey (IDHS) 2007 IMR shows a figure of 34 per 1,000 live births and a decrease in 2012 which amounted to 32 deaths per 1,000 live births and the majority of infant deaths occur in neonates $(\mathrm{MOH}$, 2013). Riskesdas 2013 the prevalence of LBW in Indonesia amounted to $10.2 \%$, and the province of East Java, with the 
incidence rate of $10-15 \%$. From the results of the data obtained from RSUD Gambiran Kota Kediri in 2016 the incidence of low birth weight by $28.2 \%$ of the total number of babies admitted to the neonatal infant is numbered 1313.

LBW causes of the general nature that is factor multifactorial mother / maternal, fetal, placental, and the environment. Factor derived from the maternal age of the mother during pregnancy are too young $(<20$ years) or too old ( $>35$ years), pregnancy spacing is too short ( $<1$ year), a history of LBW earlier, physical work some hours without a break, socioeconomic (very poor, stress, etc.) weight gain during pregnancy or malnutrition, maternal smoking or drug abusers or alcohol, pregnant women with anemia, preeclampsia or hypertension, infections during pregnancy, multiple pregnancy and a baby with birth defects (Manuaba 2010)

\section{Methods}

The design of this research was observational study design with cross Sectional. The population in this study were all mothers of infants with low birth weight are treated in RSUD Gambiran Kota Kediri as many as 112 respondents. The research sample were determined based on sampling random of 88 respondents. Instruments in this study is the observation sheet (age, parity, nutritional status, and anemia gravidarum) comes from the book KIA respondents and questionnaire (stress level) using the Perceived Stress Scale. Data was analyzed use multinomial logistic regression.

\section{Results and Discussion}

\section{Effect of Age Mothers to Pregnancy} Low Birth Weight

Table 1.1 Results of statistical test with Age influence low birth weight in RSUD Gambiran Kota Kediri.

\begin{tabular}{|c|c|c|c|}
\hline \multirow{3}{*}{ Effect } & \multicolumn{3}{|c|}{ Likelihood Ratio Tests } \\
\hline & Criteria Fitting Model & Likelihood $\mathrm{K}$ & Tests \\
\hline & $\begin{array}{l}-2 \text { Log Likelihood of } \\
\text { Reduced Model }\end{array}$ & Chi-Square & Sig. \\
\hline Intercept & $9446^{\mathrm{a}}$ & .000 & 0 . \\
\hline Age & 43828 & 14822 & .001 \\
\hline
\end{tabular}

Based on table 1.1 was known that $p$-value $=0.001$, meaning $<0.05$, so that H1 was accepted. There was the influence of maternal age when pregnant with low birth weight (LBW) in RSUD Gambiran Kota Kediri.

Optimal reproductive age for women is 20-35 years old, the age at which the mother's uterus is ready to accept a pregnancy, mental mature and able to care for herself and her infant. Under 20 years of age in the womb and the mother's pelvis is not ready for pregnancy because it has not grown to adult size and reproductive organs have not been working properly. Age over 35 years has undergone degenerative cells reproduction (Manuaba, 2010)

The results of this study are consistent with results of previous studies conducted by I Gusti Ayu Widya Goddess researching Contributions Age and Parity mother of Genesis low birth weight in Sanglah Hospital Denpasar in 2012. the purpose of this research was to determine Contributions age and Parity mothers on low birth weight incidence in Sanglah Hospital in Denpasar in 2012 and the results of this study indicate $p$ value of age on the incidence of low birth weight was 0.00 where Ho refused and $\mathrm{H} 1$ accepted meaning there is a relationship between maternal age on the incidence of low birth weight (LBW)

From this research it can be concluded that there is significant influence between the age of the mother during pregnancy with the incidence of low birth weight. Age of the mother during pregnancy may be a consideration for ready pregnancy to 
prevent the problems that will arise during pregnancy, during childbirth and the baby will be born, such as the problem of low birth weight in babies born.

\section{Effect of Maternal Stress at Genesis Against Low Birth Weight}

Table 1.2 Statistical test results influence the incidence of stress level low birth weight (LBW) in RSUD Gambiran Kota Kediri.

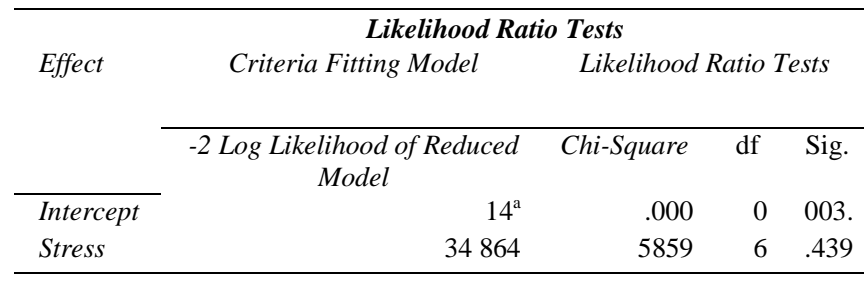

Table 1.2 Based on known that $p$-value $=$ 0.439 , meaning $<0.05$, so $\mathrm{H} 0$ is accepted. There was no effect of levels stress with Genesis low birth weight (LBW) in RSUD Gambiran Kota Kediri.

Research Alexander et al., (2014) explains that triggers chronic stress in pregnant women who are not accompanied by the ability of good stress management is associated with the birth of babies with low weight, this is due to decreased blood flow to the uterus, which can significantly affect the growth and development fetus. Premature births occur at increasing the production of corticotropin-releasing hormone $(\mathrm{CRH})$ by the placenta, this is the hormone responsible for managing the duration of the pregnancy, when levels increase will speed up the duration of the pregnancy, so the baby at risk of premature delivery and low birth weight.

But in this study of the results that have been tested show results there are no significant influence between the level of stress during pregnancy with the incidence of low birth weight (LBW). In this study, nearly half of respondents had experienced stress during pregnancy is both mild to severe. In the opinion of the researchers this is possible due to hormonal changes during pregnancy which affect the physiology. Ranging from the small to large natural mother everyday can trigger stress, but the management / stress management mothers who were respondents in this study tend to be good, so it does not affect the growth and development of the fetus

\section{Effects of Parity on Mothers to low birth weight}

table 1.3 Results of statistical test parity with the effect of low birth weight (LBW) in RSUD Gambiran Kota Kediri.

\begin{tabular}{|c|c|c|c|c|}
\hline \multirow{3}{*}{ effect } & \multicolumn{4}{|c|}{ Likelihood Ratio tests } \\
\hline & Criteria Fitting Model & Likelihood $\mathrm{K}$ & & \\
\hline & $\begin{array}{l}-2 \text { Log Likelihood of } \\
\text { Reduced Model }\end{array}$ & Chi-Square & $d f$ & Sig \\
\hline intercept & $7,258^{\mathrm{a}}$ & .000 & & 0. \\
\hline Parity & 31247 & 2,241 & 2 & .326 \\
\hline
\end{tabular}

Based on the above table it was known that $p$-value $=0.326$, meaning $<0.05$, so H0 was accepted. There was no effect of parity low birth weight (LBW) in RSUD Gambiran Kota Kediri.

Parity is the number of children born to mothers. In general, according to the development of LBW increased maternal parity, parity primiparity that women who had delivered babies with fetal weight above 2,500 g at 37-42 weeks gestation. They generally have a risk 1.32 times greater for the occurrence of LBW. BBLR risk parity was parity zero ie when first pregnant and parity more than four, it could have implications on subsequent deliveries due to the condition of the mother's womb to be born back has not recovered. The risk for $\mathrm{LBW}$ were higher in parity 0 and then will decline in the parity 1,2,3 and will increase again in the fourth parity.

But in a similar study conducted by Misna Tazkiah et al entitled epidemiological determinants of LBW in malaria-endemic areas in South Kalimantan Banjar district found that the $p$-value $=0.053$, meaning $<0.05$, so $\mathrm{H} 0$ was accepted. There was no effect of parity low birth weight (LBW). Research 
from Yunita Suwarni et al entitled The Relationship Between Parity, Lila, Hb And Age Pregnancy Birth Weight Infants With right result that the results of this study, the statistical result was obtained p-value of 1.000. This means there was no relationship between maternal parity with birth weight infants in the district of Tanah Laut Pelaihari in 2012.

However, the results of this research turned out all LBW infants born to mothers with no risk parity $(<4)$. And the number of respondents with parity at risk is only $3.4 \%$. That is, not only mothers who have parity $\geq 4$ are at risk of having LBW but mothers with parity <4, particularly women with parity 0 or nulliparous also at risk of having low birth weight. This may be due to the nulliparous mother's new pregnancy or the first time have no experience of pregnancy, so the disorder and complications experienced quite large as labor dystocia and uninformed about the pregnancy will affect the baby's birth weight. That is, women with no risk parity is also likely to give birth to low birth weight babies.

And it also means that the respondent discount awareness to follow the family planning program that is high enough so that parity tends to be low risk. Actually, in some literature that factors affect notarized incidence of low birth weight one is parity or number of children ever born. This was not out of the role of health workers who provide information about family planning and access to affordable health care for KB.

\section{Cross tabulation of nutritional status and low birth weight (LBW) in RSUD Gambiran Kota Kediri.}

Table 1.4 Statistical test results influence nutritional status and the incidence low birth weight (LBW) in RSUD Gambiran Kota Kediri.July 29 until October 2, 2017

\begin{tabular}{|c|c|c|c|c|}
\hline \multicolumn{5}{|c|}{ Likelihood Ratio Tests } \\
\hline \multirow[t]{2}{*}{ Effect } & \multirow{2}{*}{$\begin{array}{c}\text { Criteria Fitting } \\
\text { Model } \\
-2 \text { Log Likelihood } \\
\text { of Reduced Model }\end{array}$} & \multicolumn{3}{|c|}{$\begin{array}{c}\text { Likelihood Ratio } \\
\text { Tests }\end{array}$} \\
\hline & & $\begin{array}{c}\text { Chi- } \\
\text { Square }\end{array}$ & $d f$ & Sig. \\
\hline Intercept & $12^{\mathrm{a}}$ & .000 & 0 & 396. \\
\hline $\begin{array}{l}\text { Nutrition } \\
\text { Status }\end{array}$ & 33687 & 4681 & 4 & .322 \\
\hline
\end{tabular}

Based on the above table it is known that $p$-value $=0.322$, meaning $<0.05$, so $\mathrm{H} 0$ is accepted. There is no influence of nutritional status of mothers during pregnancy low birth weight (LBW) in RSUD Gambiran Kota Kediri.

Fetal malnutrition occur during pregnancy will cause growth disorders in the fetus. Pregnant women with malnutrition / protein shortage will continue into the next generation. Fetal growth normally would lead to serious complications such as stillbirth, morbidity is high and interference perinatal continue until adulthood (Hales and Barker, 1992; Wells JC, 2007)

However, in this study we can conclude there is no significant effect between maternal nutritional status during pregnancy on the incidence of low birth weight (LBW). It is possible the causes of LBW comes from other factors that have not been studied. This is possible because the pattern of the soup of nutrients that tend to be unbalanced in the mother, for example, the mother only consumes one or more types of nutrients without caring other nutrients that is important in the process of growth and development of the fetus during pregnancy.

5. Effect of anemia with low birth weight (LBW)

Table 1.5 Statistical test results influence the incidence of anemia low birth weight (LBW) in RSUD Gambiran Kota Kediri. July 29 until October 2, 2017 


\begin{tabular}{lccr}
\hline \multicolumn{4}{c}{ Likelihood Ratio tests } \\
\hline effect & Criteria & Likelihood Ratio \\
& Fitting Model & \multicolumn{2}{c}{ tests } \\
\cline { 2 - 4 } & -2 Log & Chi- & \\
& Likelihood of & Square & \\
& Reduced & & \\
& Model & & \\
Intercept & $9721^{\text {a }}$ & .000 & 0. \\
Anemia & 40837 & 11831 & 4 \\
& & & .01 \\
\hline
\end{tabular}

Based on the above table it is known that $p$-value $=0.019$, Meaning $<0.05$, so that $\mathrm{H} 1 \mathrm{was}$ accepted. There was the influence of anemia low birth weight (LBW) in RSUD Gambiran Kota Kediri.

The growth of the placenta and fetus disrupted due to a decrease in $\mathrm{Hb}$ resulting from blood volume during pregnancy, $50 \%$ up from 4 to $6 \mathrm{~L}$, plasma volume increased slightly which caused a decrease in hemoglobin concentration and hematocrit values. This decline will be smaller in pregnant women who consumed iron. (Smith et al., 2010).

A similar study conducted Simanjuntak (2009) in the district of Labuan Batu by examining the relationship of anemia in pregnant women with LBW obtained 86 (53\%) of 162 cases of anemia and give birth to babies with low birth weight $36 \%$.

This is because the lack of balanced nutritional intake in the mother during pregnancy maternal diet are likely to choose one or are several types of nutrients just let more consuming carbs and ignore foods that contain $\mathrm{Fe}$ and folate Yang was instrumental in the formation of red blood cells. Can be seen from the results of the study represent the majority (62.5) of respondents have more nutritional history but give birth to LBW babies

6. most dominant factor that influenced the incidence of low birth weight (LBW), used statistical test logistic regression multinomial follows:

Table 1.6 The most dominant factor Events that affect low birth weight (LBW) in RSUD Gambiran

\begin{tabular}{|c|c|c|c|c|}
\hline \multicolumn{5}{|c|}{ Likelihood Ratio Tests } \\
\hline \multirow[t]{2}{*}{ effect } & $\begin{array}{l}\text { Criteria } \\
\text { Fitting }\end{array}$ & \multicolumn{3}{|c|}{$\begin{array}{c}\text { Likelihood Ratio } \\
\text { Tests }\end{array}$} \\
\hline & $\begin{array}{c}-2 \text { Log } \\
\text { Likelihood } \\
\text { of Reduced } \\
\text { Model }\end{array}$ & $\begin{array}{c}\text { Chi- } \\
\text { Square }\end{array}$ & $d f$ & Sig. \\
\hline Intercept & $29^{\mathrm{a}}$ & .000 & 0 & 006 \\
\hline Age & 43828 & 14822 & 2 & .001 \\
\hline Stress & $34864^{\mathrm{b}}$ & 5,859 & 6 & .439 \\
\hline Parity & $31247^{\mathrm{b}}$ & 2,241 & 2 & .326 \\
\hline Status_gizi & $33687^{\mathrm{b}}$ & 4,681 & 4 & .322 \\
\hline Anemia & 40837 & 11831 & 4 & .019 \\
\hline
\end{tabular}

Kota Kediri.

above table shows that of all independent variable after logistic regression multinomial No 2 variables that affect the incidence of low birth weight (LBW) in RSUD Gambiran Kota Kediri.namely age and anemia. Based on these results the magnitude of the largest or dominant influence lies in the variables of age with a $p$-value $=$ 0.001 . It can be concluded that the most dominant factor influenced the incidence of low birth weight (LBW) is a factor of the age of the mother during pregnancy

contrast to research conducted Sagung Adi Sresti Mahayana (2012) which Risk Factors that Influence the incidence low birth weight in Hospital Dr. M. Djamil Padang expressed the most dominant factor is the anemia that results in getting the statistical test $p$ value of 0.001 .

\section{Conclusion}

1. There was the influence of maternal age when pregnant with low birth weight (LBW) in RSUD Gambiran Kota Kediri with a p-value $=0.001$.

2. no influence stress levels with low birth weight (LBW) in RSUD Gambiran Kota Kediri with a p-value $=0.439$

3. was no effect of parity with incident low birth weight (LBW) in RSUD 
Gambiran Kota Kediri with a p-value $=0.326$,

4. There was no influence of nutritional status of the mother during pregnancy with low birth weight (LBW) in RSUD Gambiran Kota Kediri with a p-value $=0.322$

5. There was the influence of anemia with low birth weight (LBW) in RSUD Gambiran Kota Kediri with a p-value value 0,019

6. most dominant factor influenced the incidence of low birth weight (LBW) is a factor of the age of the mother while pregnant with $\mathrm{p}$-value $=0.001$

\section{Suggestions}

1. For the respondents

in planning pregnancies during pregnancy was very important to be taken into consideration to avoid pregnancy at the age of risk, namely < 20 years or $>35$ years to prevent deliveries of LBW

2. For research places (RSUD Gambiran Kota Kediri.)

Continue to undertake the maximum effort in the form of human resources and the infrastructure to deal with its babies with low birth weight to avoid complications that may arise.

3. For researchers Subsequently

With the limitations of the study, expected that the results of this study can be used as a reference for further research by adding other variables that affect the incidence of low birth weight, who directly and indirectly

\section{References}

Alexander, B.T., John Henry Dasinger, J.H., and Suttira Intapad, S. 2014. Low birth weight: impact on women's health. Clin Ther, 36(12): 1913-1923.

Brooker, S., Hotez, P.J., Bundy, D.A.P. 2008. Hookworm-Related Anaemia Among Pregnant Women: A Systematic Review. Plos Neglected Tropical Diseases. Volume 2. Issue 9. E 291.
Depkes RI. 2008. Modul (Buku Acuan) Manajeman Bayi Baru Lahir Rendah (BBLR) untuk Bidan di Desa. Jakarta : Departemen Kesehatan RI.

Depkes RI. 2013. Laporan Hasil Riset Kesehatan Dasar (Riskesdas) Nasional Tahun 2013. Jakarta: Departemen Kesehatan RI.

Depkes RI. 2016. Jakarta : Departemen Kesehatan RI.

Dewie Sulistyorini, S. SiT, M. Kes, Shinta Siswoyo Putri, S. SiT,M. Kes. Analisis Faktor-faktor yang Mempengaruhi kejadian BBLR di Puskesmas pedesaan Kabupaten Banjarnegara tahun 2014. Medsains Vol. 1 No. 01, Maret 2015 : 23-29.

Ginsburg, A.., Izadnegahdar, R., , Berkley, J.A., Walson, J.R., Rollin, N., dan Klugman, K P. 2015. Undernutrition and pneumonia mortality. The Lancet Global Health, vol. 3, no. 12, hlm. 735736.

Kementrian Kesehatan Republik Indonesia. 2016. Profil Kesehatan Indonesia Tahun 2015. Jakarta: Kementrian Kesehatan Republik Indonesia.

Manuaba. 2012. Ilmu kebidanan, penyakit kandungan dan KB untuk Pendidikan Bidan, Edisi 2. Jakarta : EGC.

Maryati, D. 2011. Penatalaksanaan pada Bayi Resiko Tinggi. Jakarta: Rineka Cipta.

Misna Tazkiah, dkk. (2013). Determinan Epidemiologi Kejadian BBLR Pada Daerah Endemis Malaria Di Kabupaten Banjar Provinsi Kalimantan Selatan. Surabaya : Jurnal Berkala FKM Universitas Airlangga

Murti, B. 2013. Desain dan Ukuran Sampel untuk Penelitian Kuantitatif dan Kualitatif di Bidang Kesehatan. Yogyakarta: Gadjah Mada University Press.

Nurmalasari, D. (2014). Gambaran Faktor Resiko Bayi Berat Badan Lahir Rendah Dirumah Sakit Umum Pusat Fatmawati Pada Tahun 2014. In Laporan Tugas akhir. jakarta: UIN Syarif Hidayatullah. 
Proverawati, A.,\& Ismawati, C.2010. Berat Bayi Lahir Rendah. Yogyakarta: Nuha Medika

Sagung Adi Sresti Mahayana, dkk.2012. Faktor Risiko yang Berpengaruh terhadap Kejadian Berat Badan Lahir Rendah di RSUP Dr. M. Djamil Padang : FK UNAND

Saifuddin, A. B. 2007. Buku Acuan Nasional Pelayanan Kesehatan Maternal dan Neonatal. Jakarta : Yayasan Bina Pustaka Sarwono Prawirohardjo.

S,A Rizvi,dkk.2007. Maternal Risk Factors Associated With Low Birth Weght in Karawaci : a Case Control Stud. Karawaci : Health meditterraneant journal

The United Nations Children's Fund (UNICEF) (2004) Low Birth Weight: Country, Regional and Global Estimates. UNICEF, New York.

Varney H. 2006. Buku Ajar Asuhan Kebidanan. Jakarta : EGC

Wong, D., Eaton, M. H., Wilson, D., Winkelstein, M., \& Schwartz, P. (2008).Buku Ajar Keperawatan Pediatrik (6 ed., Vol. 1). jakarta: Buku Kedokteran EGC.

Rini, S.S., Trisna I.W. 2012. Faktor-Faktor Resiko Kejadian Berat Bayi Lahir Rendah di Wilayah Kerja Unit Pelayanan Terpadu Kesmas Gianyar II. Bali : Program Studi Pendidikan Dokter, Fakultas Kedokteran Universitas Udayana.

Vitrianingsih, dkk .2012. Faktor-faktor yang berhubungan dengan Berat lahir bayi di RSUD wonosari gunungkidul ogyakarta tahun 2012. Bali : Universitas Udayana Balipneumonia anak balita di RSUD Bangkinang Kabupaten Kampar. Jurnal Kesehatan Komunitas, 136-141.

Riset Kesehatan Dasar (Riskesdas), 2013. Jakarta: Badan Penelitian dan Pengembangan Kesehatan Kementerian Kesehatan RI; 2013.

Rosmawati, Y., \& Ruhyana. 2014. Analisis faktor status gizi dan imunisasi yang mempengaruhi kejadian jenis pneumonia pada balita di RSUD
Panembahan Senopati Bantul Yogyakarta. Ilmu Keperawatan STIKes 'Aisyiah.

Rudan ,I.,Pinto, C.B.,Biloglav, Z.,Mulholland, K., Campbell, H. 2008. Epidemiology and Etiology of Childhood Pneumonia. Bulletin Of World Health Organization 86:408-416

Rudolph, A.M., Hoffman, J.I., Rudolph,C.D. 2006. Buku AjarPpediatri Rudolph vol 3.Jakarta : EGC

Sari, EL., Suhartono \& Joko, T. (2014).Hubungan antara kondisi lingkungan fisik dengan kejadian pneumonia pada balita di wilayah kerja Puskesmas Pati I Kabupaten Pati. Jurnal Kesehatan Masyarakat, Vol. 1(1)

Schulte, Elizabeth ,B. 2001. Thompson's Pediatric Nursing. Philadelphia : Saunders company

Setiawan, R., Ida \& Budi. 2010. Hubungan status gizi dengan kejadian pneumonia pada anak balita di wilayah kerja Puskesmas Palasari Kecamatan Ciater Kabupaten Subang. Ilmu Keperawatan Poltekes Bandung, 1-10.

Somantri,I.2008. Asuhan Keperawatan Pasien dengan Gangguan Sistem Pernapasan.Jakarta: Salemba Medika

Steven,P,S.,Hannemann, R, E.2004.Panduan lengkap untuk bayi dan balita.Jakarta: Arcan

Suhardjo. 2006. Berbagai Cara Pendidikan Gizi. Jakarta: Bumi Aksara

Supariasa, D. N., B. Bakri, dan I. Fajar, 2002.Penilaian Status Gizi.Jakarta: EGC.

Supriyatin, O., \& Sulistyaningsih. 2015. Hubungan paparan asap rokok dan rumah tidak sehat dengan kejadian pneumonia pada balita di Puskesmas Wirobrajan Yogyakarta. Ilmu Kebidanan STIKes 'Aisyiyah Yogyakarta.

Widayat, A. 2014. Faktor-faktor yang berhubungan dengan kejadian pneumonia pada balita di wilayah kerja Puskesmas Mojogedang II Kabupaten 
Karanganyar. Kesehatan Masyarakat Universitas Muhammadiyah Surakarta.

Wong, Donna L. 2008. Buku Ajar Keperawatan PediatricVvolume 2.Jakarta : EGC.

World Health Organization.Adolescent Health. Available from:http:// www.who.int/topics/adolescent_health/e n/. Diakses tanggal 10 Pebruari 2017.

World Health Organization., 2015. Health in 2015 from MDGs to SDGs. http://www.who.int/gho/publications/m dgs-sdgs/MDGsSDGs2015_ chapter4_snapshot_child_health.pdf [diakses pada tanggal 10 Pebruari 2017].

Zairinayati, Udiyono, A., \& Hanani, Y. 2013. Analisis faktor lingkungan fisik rumah yang berhubungan dengan kejadian pneumonia pada balita di wilayah kerja Puskesmas Sosial Kecamatan Sukarame Palembang. Jurnal Kesehatan Lingkungan Universitas Diponegoro, 11-20 